\title{
Carotenoid feed supplementation in Argentine penaeoid shrimp broodstock
}

\author{
Ana Cristina Díaz ${ }^{1,2}$, María Laura Espino ${ }^{1}$, Emiliano Pisani ${ }^{3}$ \\ Susana M. Velurtas ${ }^{1} \&$ Jorge L. Fenucci ${ }^{1}$ \\ ${ }^{1}$ Instituto de Investigaciones Marinas y Costeras (UNMDP-CONICET), Mar del Plata, Argentina \\ ${ }^{2}$ Comisión de Investigaciones Científicas, La Plata, Argentina \\ ${ }^{3}$ Instituto Nacional de Investigación y Desarrollo Pesquero, Mar del Plata, Argentina \\ Corresponding author: Ana Cristina Díaz (acdiaz@mdp.edu.ar)
}

\begin{abstract}
This work aimed to improve reproductive maturation in two penaeoid species (Artemesia longinaris and Pleoticus muelleri) by using carotenes added in artificial feeds and comparing antioxidant activity and carotenoids profiles. Immature females were kept for 45 days at salinity 33, temperature at $18^{\circ} \mathrm{C}, \mathrm{pH} 7$, 12:12 $\mathrm{h}$ photoperiod, ammonium $<0.2 \mathrm{mg} \mathrm{L}^{-1}$ and seawater exchanged at $100 \%$ per day. Feeding regimes consisted of 50\% fresh frozen ingredients (clam muscle and squid mantle) and 50\% dry pellets. For each species, three pelletized feeds were tested, one as a control (C) and two supplemented each one with $300 \mathrm{mg}$ astaxanthin (A) and $\beta$-carotene (B) $\mathrm{kg}^{-1}$ of diet. At the end of the trials, ovaries, midgut gland, and integument were sampled. In both species, the addition of carotenoids improved ovarian development: $100 \%$ of females fed A or B diets were mature, but of the females fed with diet C only $75 \%$ (P. muelleri) and 64\% (A. longinaris) matured. Ovaries of mature females exhibited the highest concentration of carotenoids. The abundance of free astaxanthin regarding total carotenes, suggests that excess of free astaxanthin could be biotransformed to esterified astaxanthin. The scavenging properties were evaluated against the stable 1,1-diphenyl-2-picrylhydrazyl (DPPH) radical by electron resonance spectroscopy (EPR). For all feed treatments, the extracts exhibited strong DPPH scavenging activity, without significant differences among them.
\end{abstract}

Keywords: Artemesia longinaris; Pleoticus muelleri; crustacean; maturation; nutrition; supplemented feed

\section{INTRODUCTION}

The prawn Artemesia longinaris Spence Bate, 1888, and the red shrimp Pleoticus muelleri (Spence Bate, 1888) are two Argentine native penaeid species distributed along the southwestern Atlantic coastal waters, from Rio de Janeiro (Brazil) to Patagonia (Argentina). Both with high commercial value and potential for culture in temperate-zone. It is advisable to perform complete cycle in captivity, or at least capture impregnated females at sea, rear the larvae and make them grow to market size. For this, it is essential to understand the biology of these species, which requires understanding maturation processes, mating, larval culture, fattening, and special nutritional requirements.

The use of an optimal diet is known to be a crucial factor for sexual maturation and reproduction. Most shrimp broodstock diets consist of fresh-frozen seafood such as squid, mussels, worms, and clams, among others, but the nutritional quality of these foods can vary according to season. Fresh-foods also present several disadvantages, such as the increased risk of disease transmission, variable nutritional quality, unpredictable supply, and the potential to cause deterioration of water quality in hatchery culture systems (Harrison, 1990, 1997). The use of pelletized diets is advantageous because they are easier to manage, store, and they present less danger of pathogenic contamination (Wouters et al., 2002). Commercially available broodstock pellets have been successfully used to replace fresh compounds in various proportions. Prepared dry feeds are frequently used as supplements comprising $20-50 \%$ of a maturation diet (Bray et al., 1990; Díaz \& Fenucci, 2004; Ghorbani-Vaghei et al., 2017).

Use of bioactive substances such as nutritional additives to improve cultured shrimp yields is receiving

Corresponding editor: Mariel Gullian 
increased attention, for example, there are efforts to define the biological function of carotenoids as a dietary supplement (Huang et al., 2008; Sawanboonchun et al., 2008; Niu et al., 2012). Carotenoids are a group of pigments that cannot be biosynthesized by animals; therefore, these must be incorporated through diet or by metabolic transformation derivative of some dietary carotenoid. In crustacean, carotenoids' metabolic route involves an oxidative sequence that starts with $\beta$ carotene of dietary origin involving hydroxy or ketocarotene carotenoids as intermediaries, and its final product is astaxanthin (Katayama et al., 1973). Benefits of carotenoids in the diet include stimulating the immune system, increasing tolerance to stress, improving embryonic and larval development (Regunathan \& Wesley, 2006), and enhancing reproduction and maturation of shrimp broodstock (Pangantihon-Kühlmann et al., 1998; Paibulkichakul et al., 2008). Additionally, carotenoids are a source of vitamin A (Liñán-Cabello et al., 2002).

Carotenoids also play an essential role in animal health as antioxidants through the inactivation of free radicals produced from regular cellular activity and various stressors (Chew, 1995). The antioxidant behavior of a carotenoid molecule depends on its structure and the nature of the oxidizing species itself. Quenching constants for ${ }^{1} \mathrm{O}_{2}$ is directly related to the position of conjugated double bonds but may be influenced by other structural features as the nature and position of substituent groups on the carotenoid molecule (Young \& Lowe, 2001). Consequently, carotenoids have been reported to be the most efficient quenchers of singlet oxygen $\left({ }^{1} \mathrm{O}_{2}\right)$ and the astaxanthin as a member of the carotenoid family reduces the oxidation rate ( $\mathrm{Pu}$ et al., 2010).

The body produces several endogenous antioxidants capable of scavenging these harmful reactive oxygen species (ROS) to maintain an optimal oxidantantioxidant balance. However, under conditions of high oxidative stress, these antioxidants' ability to eliminate ROS is often inadequate and, therefore, dietary sources of antioxidants or drugs are required (Chew \& Park, 2004). Free radical scavenging activity of carotenoids can be evaluated by spectroscopy and electron paramagnetic spin resonance (EPR) spectroscopy methods, considered the most accurate method for detecting free radicals (Halliwell \& Gutteridge, 2001).

The present study focused on improving the maturity of reproductive shrimp stocks of A. longinaris and $P$. muelleri, by using bioactive substances like carotenes (astaxanthin and $\beta$-carotene) added in artificial feeds, to define their potential as bioactive dietary supplements, comparing antioxidant activity and carotenoids profiles.

\section{MATERIALS AND METHODS}

\section{Chemicals}

The DPPH standard was obtained from Aldrich. Astaxanthin (98\%) and $\beta$-carotene (93\%) were obtained from Sigma-Aldrich and stored in the dark at $253 \mathrm{~K}$. All other reagents were analytical grade. The solvents were from Merck, and they were carefully purified following the literature method to have them free of alkenes and carbonyl compounds. All solvents used were dried conveniently.

\section{Experimental conditions}

Experiments were carried out with immature females of the two penaeid species, Pleoticus muelleri (initial mean weight of $18.5 \pm 4.37 \mathrm{~g}$ ) and Artemesia longinaris (initial mean weight of $2.55 \pm 0.71 \mathrm{~g}$ ) obtained from the coastal waters of Mar del Plata, Argentina $\left(38^{\circ} 05^{\prime} \mathrm{S}\right.$, $57^{\circ} 00^{\prime} \mathrm{W}$ ). They were held at Nagera Station (Marine Science Department, Mar del Plata National University, Argentina) in black circular tanks of 3,500 L with aeration. During the first week, shrimp were fed squid mantle for acclimatization. Later, a random sample of three immature females of each species was collected for initial body carotenoid analysis (initial). Females were unilaterally eyestalk ablated by cutting with ophthalmologic scissors close to the carapace (Díaz \& Fenucci, 2004). Experimental conditions were: water temperature between $20-21^{\circ} \mathrm{C}$, salinity $33, \mathrm{pH} 7$, ammonium $<0.2 \mathrm{mg} \mathrm{L}^{-1}$, photoperiod 12:12 $\mathrm{h}$; seawater was exchanged entirely daily, and the temperature was maintained with an L style heaters of titanium. Gonad development was monitored daily. Females were classified according to Petriella \& Díaz (1987): stages I, II, III, and IV as mature and stage V as immature. At the beginning and the end of the experiment, animals were weighed and tagged (Díaz \& Fenucci, 2004). At the end of the experiment, mature females from each treatment were dissected, and ovaries, integument, and midgut gland were extracted and lyophilized. Ovaries and integument were used to analyze carotenoids and the midgut gland to analyze the antioxidant activity.

\section{Feeding trials}

After the acclimation period, three groups of 40 immature females of each species were used for the feeding trials. For 45 days, the feeding regimes consisted of $50 \%$ fresh frozen ingredients (squid mantle and clam muscle, with no carotenoid detected in their composition at a ratio of 1.5:1) and 50\% dry feed pellets (Table 1). Three feed was tested in duplicate; two supplemented with two different carotenoids: astaxanthin (A) and $\beta$-carotene (B), each at a concentration of $300 \mathrm{mg} \mathrm{kg}^{-1}$ diet and formulated diet without carote- 
Table 1. Ingredient composition of experimental feeds. ${ }^{a}$ Agustinier S.A. Mar del Plata, Argentina, ${ }^{b}$ Melrico S.A. Argentina, ${ }^{\mathrm{c}} \mathrm{g} \mathrm{kg}^{-1}$ : cholecalciferol 1.8, thiamin 8.2, riboflavin 7.8, pyridoxine 10.7, calcium pantothenate 12.5, biotin 12.5, niacin 25.0, folic acid 1.3, $\mathrm{B}_{12} \mathrm{HCl}$ 1.0, ascorbic acid (Rovimix Stay C) 39.1, menadione 1.7, inositol 0.3, choline chloride 0.2, $\alpha$-tocopherol acetate 75, vitamin A acetate 5.0.

\begin{tabular}{|c|c|c|c|c|c|}
\hline \multirow[b]{2}{*}{ Ingredient $\left({\left.\mathrm{g} 100 \mathrm{~g}^{-1}\right)}\right.$} & \multicolumn{3}{|c|}{ Experimental feed } & & \\
\hline & $\mathrm{C}$ & A & B & & \\
\hline Fishmeal $(65 \% \text { crude protein })^{\mathrm{a}}$ & 41.5 & 41.5 & 41.5 & & \\
\hline Squid meal (78\% crude protein) & 25.0 & 25.0 & 25.0 & & \\
\hline Clam meal ( $73 \%$ crude protein) & 4.0 & 4.0 & 4.0 & & \\
\hline Soybean meal $(42 \% \text { crude protein })^{b}$ & 4.5 & 4.5 & 4.5 & & \\
\hline Manioc starch & 15.0 & 15.0 & 15.0 & & \\
\hline Astaxanthin & 0 & & 0 & & \\
\hline$\beta$-carotene & 0 & 0 & & & \\
\hline Fish oil & 3.0 & 3.0 & 3.0 & & \\
\hline Fish soluble & 3.0 & 3.0 & 3.0 & & \\
\hline Soybean lecithin & 1.0 & 1.0 & 1.0 & & \\
\hline Cholesterol & 1.0 & 1.0 & 1.0 & & \\
\hline Vitamins supplement $^{\mathrm{c}}$ & 0.5 & 0.5 & 0.5 & & \\
\hline \multicolumn{6}{|l|}{ Proximate composition (\% dry matter) } \\
\hline Moisture & 7.0 & 7.0 & 7.0 & & \\
\hline Crude protein & 54.5 & 54.5 & 54.5 & & \\
\hline Total lipid & 13.7 & 13.7 & 13.7 & & \\
\hline Ash & 7.0 & 7.0 & 7.0 & & \\
\hline Ingredient $\left({\left.\mathrm{g} 100 \mathrm{~g}^{-1}\right)}\right.$ & $\mathrm{C}$ & A & $\mathrm{B}$ & Clam muscle & Squid mantle \\
\hline Fishmeal $(65 \% \text { crude protein })^{\mathrm{a}}$ & 41.5 & 41.5 & 41.5 & & \\
\hline Squid meal ( $78 \%$ crude protein) & 25.0 & 25.0 & 25.0 & & \\
\hline Clam meal ( $73 \%$ crude protein) & 4.0 & 4.0 & 4.0 & & \\
\hline Soybean meal ( $42 \%$ crude protein $)^{b}$ & 4.5 & 4.5 & 4.5 & & \\
\hline Manioc starch & 15.0 & 15.0 & 15.0 & & \\
\hline Astaxanthin & 0 & 0.03 & 0 & & \\
\hline$\beta$-carotene & 0 & 0 & 0.03 & & \\
\hline Fish oil & 3.0 & 3.0 & 3.0 & & \\
\hline Fish soluble & 3.0 & 3.0 & 3.0 & & \\
\hline Soybean lecithin & 1.0 & 1.0 & 1.0 & & \\
\hline Cholesterol & 1.0 & 1.0 & 1.0 & & \\
\hline Vitamins supplement $^{\mathrm{c}}$ & 0.5 & 0.5 & 0.5 & & \\
\hline \multicolumn{6}{|l|}{ Proximate composition (\% dry matter) } \\
\hline Moisture & 7.0 & 7.0 & 7.0 & 79.4 & 82.5 \\
\hline Crude protein & 54.5 & 54.5 & 54.5 & 71.8 & 78.0 \\
\hline Total lipid & 13.7 & 13.7 & 13.7 & 3.9 & 15.0 \\
\hline Ash & 7.0 & 7.0 & 7.0 & 2.2 & 1.9 \\
\hline
\end{tabular}

noid supplementation served as control (C); this feed

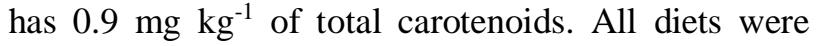
analyzed by methods of the Association of Analytical Chemists (AOAC, 1997). Dietary ingredients were mixed and cold pelletized by extrusion $\left(<50^{\circ} \mathrm{C}\right)$ to obtain $3 \mathrm{~mm}$ diameter pellets, oven-dried at $50^{\circ} \mathrm{C}$ for $24 \mathrm{~h}$, air-dried, flushed with argon gas, and stored in darkness at $-4^{\circ} \mathrm{C}$. Animals were fed "ad libitum" three times a day (09:00, 13:00 and 17:00 h). The feeding rate was adjusted daily to minimize feed waste. Individual shrimp weights were determined at the beginning of the experiment and after 45 days. Growth performance and survival were measured in terms of final individual weight, percentage of weight gain [[(final mean weight - initial mean weight) / initial mean weight] $\times 100$ ], and percentage of survival.

\section{Carotenoid analysis}

The dissected parts were freeze-dried. Lyophilized samples were homogenized in an argon atmosphere in darkness, and carotenoids were analyzed following the technique proposed by Schiedt et al. (1993) and modified by Díaz et al. (2013). $\beta$-carotene was extracted three times with hexane in an argon atmos- 
phere in darkness, and free astaxanthin was separated by partitioning with dimethyl sulphoxide (DMSO)/ acetone (1:3) until colorless in an inert atmosphere.

Absorption peaks of the carotenoids were identified by scanning the spectrum between 200 and $750 \mathrm{~nm}$ using a diode array spectrophotometer (Shimadzu UV2102 PC, UV/Visible Scanning Spectrophotometer). Carotenoid concentrations were calculated using standard curves of $\beta$-carotene in hexane $\left(1.88 \times 10^{-6} \mathrm{M}\right)$ and astaxanthin in $\mathrm{DMSO} /$ acetone $\left(4.19 \times 10^{-6} \mathrm{M}\right)$ using the specific extinction coefficients 122,000 and $124,000 \mathrm{M}^{-1}$ $\mathrm{cm}^{-1}$, respectively (Britton et al., 1995).

\section{Electronic paramagnetic resonance (EPR) measure- ments}

Antioxidant activity of lyophilized midgut gland was investigated based on the scavenging activity on the stable 1,1-diphenyl-2-picrylhydrazyl radical (DPPH) using EPR with a Bruker ELEXSYS E $500 \mathrm{~T}$ spectrometer, operating at X-band. About $25 \mathrm{mg}$ of tissue of each treatment was mixed with $1 \mathrm{~mL}$ of chloroform in an argon atmosphere and darkness. Aliquots of $50 \mu \mathrm{L}$ with $50 \mu \mathrm{L}$ of DPPH solution $\left(1.53 \times 10^{-5} \mathrm{M}\right)$ were analyzed at a constant room temperature of $19.85^{\circ} \mathrm{C}$ and at fixed time intervals for 60 min. Control or blank preparations containing $50 \mu \mathrm{L}$ of DPPH in chloroform solvent remained unaltered after an extended period, DPPH proved to be a very stable free radical (Díaz et al., 2014); the intensity of the signal decays with time and represents the radicaltissue reaction. Amplitude signals were transformed in radical concentrations by comparing the area under the EPR absorption spectrum of the sample to a chloroform solution of the concentration standard, DPPH. Measurements were repeated at least three times to minimize random errors. The standard plotting program Origin Pro was used to fit all sets of points whenever necessary.

\section{Statistical analysis}

The percentage gain in mean weight and tissue carotenoid content was calculated. Results were presented as mean \pm standard error. Statistical differences among the experimental data were determined using analysis of variances (ANOVA) to compare means. For all analyses, statistical differences were considered significant at $P<0.05$ (Sokal \& Rohlf, 1995).

\section{RESULTS}

\section{Feeding trials}

After 45 days of feeding immature females with combined diets (natural food organisms and pellets), maturation was $100 \%$ in individuals fed with diets supplemented with both carotenoids. However, only 75 and $64 \%$ of $P$. muelleri and A. longinaris females fed control diet reached maturity (Table 2).

Survival in all treatments was high for A. longinaris, ranging between 80 and $95 \%$, while $P$. muelleri varied between 60 and $70 \%$ (Table 2). Neither penaeid species showed a significant difference in the survival percentage between treatments.

Significant differences were determined for weight gain between control and treatments with carotenoids, in A. longinaris, percentage increment in mean weight varied between 56.7 and $81.0 \%$. In P. muelleri, there were no statistical differences in weight gain between treatments, with values ranging between 20.8 and $24.9 \%$ (Table 2).

\section{Carotenoid analysis}

Carotenoid composition of integument and ovaries are shown in Tables 3 and 4. In both species, results of quantitative analysis of the carotenoid showed that $\beta$ carotene was more abundant that astaxanthin in initial animals and those under experimentation.

Concentrations of $\beta$-carotene in integument were similar among treatments in both species; however, amount of this compound in initial shrimp was lower, with values of $1.67 \pm 0.62$ and $0.63 \pm 0.06 \mu \mathrm{g} \mathrm{g}^{-1}$ for $P$. muelleri and A. longinaris, respectively.

Integument concentrations of astaxanthin of $P$. muelleri fed $\operatorname{diet} \mathrm{B}\left(0.46 \pm 0.06 \mu \mathrm{g} \mathrm{g}^{-1}\right)$ were significantly lower than animals fed with other diets and initial animals. The highest levels of this compound were found in animals fed with diets $\mathrm{C}(1.26 \pm 0.23 \mu \mathrm{g}$ $\left.\mathrm{g}^{-1}\right)$ and $\mathrm{A}\left(1.15 \pm 0.31 \mu \mathrm{g} \mathrm{g}^{-1}\right)$. Values for A. longinaris were: $0.71 \pm 0.09 \mu \mathrm{g} \mathrm{g}^{-1}$ (initial), $0.79 \pm 0.56 \mu \mathrm{g} \mathrm{g}^{-1}$ (fed $\operatorname{diet} \mathrm{C})$ and $0.81 \pm 0.33 \mu \mathrm{g} \mathrm{g}^{-1}($ fed $\operatorname{diet} \mathrm{A})$.

Ovarian $\beta$-carotene content was similar in both species ranging between $5.35 \pm 1.30$ to $3.19 \pm 0.55 \mu \mathrm{g}$ $\mathrm{g}^{-1}$ in $P$. muelleri, and from $4.37 \pm 0.16$ to $2.03 \pm 0.39$ $\mathrm{mg} \mathrm{g}^{-1}$ in A. longinaris. For both species, astaxanthin values in ovaries of animals fed diet $A$ were significantly higher than to initial.

\section{Electronic paramagnetic resonance (EPR) measure- ments}

Antioxidant protective capacity in $P$. muelleri, measured as the DPPH radical's decay with time, showed antioxidant protective capacity in all the treatments, without significant differences among treatments (Fig. 1a). Similar kinetics curves were observed for initial and captive shrimps; however, the lowest activity was determined in initial organisms' samples. 
Table 2. Percentage of mature female, average weight gain and survival rate of Pleoticus muelleri and Artemesia longinaris fed different feeding regimes. MF: mature female percentage, GWP: gain weight percentage, S: survival. Values are means of two testing tanks. Different superscript letters in the same row show statistical differences $(P<0.05)$.

\begin{tabular}{lccccccc}
\hline \multirow{2}{*}{ Diet } & \multicolumn{3}{c}{ Pleoticus muelleri } & & \multicolumn{3}{c}{ Artemesia longinaris } \\
\cline { 2 - 4 } \cline { 6 - 8 } & $\mathrm{C}$ & $\mathrm{A}$ & $\mathrm{B}$ & & $\mathrm{C}$ & $\mathrm{A}$ & $\mathrm{B}$ \\
\hline MF $(\%)$ & $75^{\mathrm{a}}$ & $100^{\mathrm{b}}$ & $100^{\mathrm{b}}$ & & $64^{\mathrm{a}}$ & $100^{\mathrm{b}}$ & $100^{\mathrm{b}}$ \\
GWP $(\%)$ & $20,76^{\mathrm{a}}$ & $24,94^{\mathrm{a}}$ & $23,78^{\mathrm{a}}$ & & $56,74^{\mathrm{a}}$ & $79,58^{\mathrm{b}}$ & $81^{\mathrm{b}}$ \\
S $(\%)$ & $70^{\mathrm{a}}$ & $60^{\mathrm{a}}$ & $70^{\mathrm{a}}$ & & $95^{\mathrm{a}}$ & $80^{\mathrm{a}}$ & $90^{\mathrm{a}}$ \\
\hline
\end{tabular}

Table 3. Carotenoids concentration ( $\mu \mathrm{g} \mathrm{g}^{-1}$ tissue) in integument and ovary of initial and captive shrimp Pleoticus muelleri fed with different feeding regimes. Values are means \pm standard error; $n=3$. Means in a row with different superscript letters significantly differ $(P<0.05)$.

\begin{tabular}{lcccc}
\hline & \multirow{2}{*}{ Initial } & \multicolumn{3}{c}{ Experimental diet } \\
\cline { 3 - 5 } & & $\mathrm{C}$ & $\mathrm{A}$ & $\mathrm{B}$ \\
\hline$\beta$-carotene & & & & \\
\hline Integument & $1.67 \pm 0.62^{\mathrm{a}}$ & $1.93 \pm 0.40^{\mathrm{b}}$ & $1.90 \pm 0.55^{\mathrm{b}}$ & $2.04 \pm 0.20^{\mathrm{b}}$ \\
\hline Ovary & $3.88 \pm 0.17^{\mathrm{a}}$ & $5.32 \pm 0.52^{\mathrm{b}}$ & $3.19 \pm 0.55^{\mathrm{a}}$ & $5.35 \pm 1,30^{\mathrm{b}}$ \\
\hline Astaxanthin & & & & \\
\hline Integument & $1.05 \pm 0.09^{\mathrm{a}}$ & $1.26 \pm 0.23^{\mathrm{a}}$ & $1.15 \pm 0.31^{\mathrm{a}}$ & $0.46 \pm 0.06^{\mathrm{b}}$ \\
\hline Ovary & $0.90 \pm 0.23^{\mathrm{a}}$ & $1.92 \pm 0.10^{\mathrm{b}}$ & $2.15 \pm 0.65^{\mathrm{b}}$ & $2.89 \pm 0.11^{\mathrm{b}}$ \\
\hline
\end{tabular}

Table 4. Carotenoids concentration ( $\mu \mathrm{g} \mathrm{g}^{-1}$ tissue) in integument and ovary of initial and captive shrimp Artemesia longinaris fed with different feeding regimes. Values are means \pm standard error; $\mathrm{n}=3$. Means in a row with different superscript letters significantly differ $(P<0.05)$.

\begin{tabular}{lcccc}
\hline & \multirow{2}{*}{ Initial } & \multicolumn{3}{c}{ Experimental diet } \\
\cline { 3 - 5 } & & $\mathrm{C}$ & $\mathrm{A}$ & $\mathrm{B}$ \\
\hline B-carotene & & & & \\
Integument & $0.63 \pm 0.06^{\mathrm{a}}$ & $2.85 \pm 0.92^{\mathrm{b}}$ & $4.69 \pm 1.38^{\mathrm{b}}$ & $3.32 \pm 0.24^{\mathrm{b}}$ \\
Ovary & $3.70 \pm 0.55^{\mathrm{a}}$ & $3.63 \pm 0.24^{\mathrm{a}}$ & $4.37 \pm 0.16^{\mathrm{b}}$ & $2.03 \pm 0.39^{\mathrm{c}}$ \\
Astaxanthin & & & & \\
Integument & $0.71 \pm 0.09^{\mathrm{a}}$ & $0.79 \pm 0.56^{\mathrm{a}}$ & $0.81 \pm 0.33^{\mathrm{a}}$ & $0.21 \pm 0.05^{\mathrm{b}}$ \\
Ovary & $0.6 \pm 0.15^{\mathrm{a}}$ & $0.70 \pm 0.17^{\mathrm{a}}$ & $1.07 \pm 0.24^{\mathrm{b}}$ & $0.82 \pm 0.19^{\mathrm{c}}$ \\
\hline
\end{tabular}

Antioxidant protective capacity in A. longinaris (Fig. 1b) showed significant differences between treatments respect to initial. The signal decayed at three minutes around $70 \%$ in captive animals and $50 \%$ in initial ones, recording a DPPH remaining $12 \%$ in the initial after 12 min, unlike treatments C (3\%), B (6\%), and $\mathrm{A}(6 \%)$.

\section{DISCUSSION}

Under captive conditions, broodstock shrimps are fed with fresh or fresh-frozen food to ensure optimal reproductive output; however, studies of alternative diets are necessary to avoid the disadvantages of using fresh food. Most shrimp broodstock diets consist of fresh-frozen seafood such as squid, mussels, worms, and clams, among others, but the nutritional quality of these foods can vary according to season. Commercially available broodstock pellets have been successfully used to replace the fresh compounds in various proportions. Prepared dry feeds are frequently used as supplements comprising 20-25\% of a maturation diet. In a previous study conducted with Pleoticus muelleri, Díaz \& Fenucci (2004) determined that supplementation of fresh food with $15 \%$ of dry feed, significantly increases the percentage of mature females compared to those fed with exclusively fresh food. Diversified diet is expected to cover broodstock's nutritional requirements, which may be why shrimp fed a mixed diet (pellets and natural food) has better spawning performance than those fed only with natural food. In the present study, 50\% substi-tution of fresh food with pelletized feeds (with and without carotenoids) promotes $100 \%$, mature females. Still, 

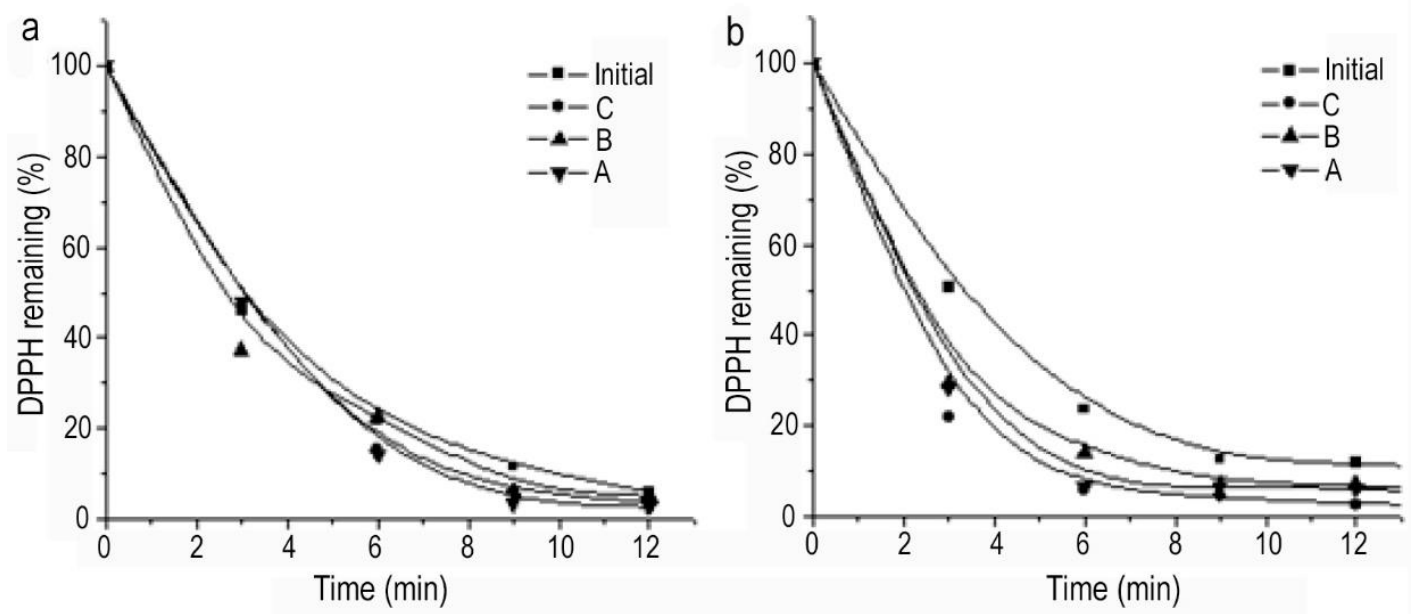

Figure 1. The kinetic reaction of tissue with the DPPH radical. Tissue extracts were tested for a pool of animals of both species fed different feeding regimes, by mixing $0.025 \mathrm{~g}$ of tissue with $50 \mu \mathrm{L}$ of DPPH solution $\left(2.8 \times 10^{-5} \mathrm{M}\right)$. All tests were conducted in triplicate, and the means are used. a) Pleoticus muelleri, b) Artemesia longinaris. Values are the mean of three determinations.

those fed with a control diet only matured $75 \%(P$. muelleri) and 64\% (Artemesia longinaris). Similar results were obtained by Wouters et al. (2002) in Penaeus vannamei (Boone, 1931); these authors concluded that substituting $50 \%$ of the fresh food with artificial broodstock feed is feasible because fresh food replacement did not affect the response variables negatively. More recently, Ghorbani-Vaghei et al. (2017) showed that substitution of 50\% of fresh foods for pelleted diets improves reproduction indices.

Feeding crustaceans in intensive farming is limited to artificial diets, which may lack critical bioactive metabolites for growth and survival. Previous studies have shown an increase in survival of different species due to carotenoids inclusion in artificial diets, although data on growth were having a wide-ranging. In some species of shrimp as $P$. vannamei and $P$. monodon Fabricius, 1798 (Niu et al., 2009, 2012, respectively), survival and growth are improved by supplementation with various carotenoids. However, in Marsupenaeus japonicus (Spence-Bate, 1888), only survival was enhanced (Chien \& Shiau, 2005). In the present study, survival was not influenced by the inclusion of carotenoids in both $P$. muelleri and A. longinaris; however, the latter showed a higher percentage of survival. Carotenoid supplementation not produced variations in the growth of $P$. muelleri, as in previous work with juveniles of the same species (Díaz et al., 2011), but they increased significantly weight gain of A. longinaris for $\beta$-carotene $(81 \%)$ and astaxanthin (79.6\%) treatments.

The effects of carotenoids could be related to the transcription of hormone genes directly involved in the ovary's maturation. The action of hormones such as gonad stimulating, crustacean hyperglycemic, gonad inhibitory, and red pigment concentrating hormone could be involved (Liñán-Cabello \& Paniagua-Michel, 2004). The high levels of ovarian carotenoids in mature females (initial and reared) suggest that dietary carotenoids work not only as a source of pigments but so as a source of precursor molecules for metabolic conversion to retinoids and other bioactive molecules (Bonnie et al., 1994; Beckett \& Petkovich, 1999; Durica et al., 1999).

Tissue carotene analysis, both in integument and ovary, in P. muelleri and A. longinaris, showed that non-polar carotenes ( $\beta$-carotene) were more abundant than polar ones (free astaxanthin). The smaller ratio of free astaxanthin concerning $\beta$-carotene can be related to the fact that free astaxanthin suffers biotransformation towards esterify astaxanthin, storing itself as lipidic globules or forming complexes of carotenoproteins (Wade et al., 2005). Availability of dietary carotene sources affects its content and concentration in crustaceans, total carotenoid concentrations in the tissue of the shrimp fed supplemented diets did not significantly differ from those in shrimp fed the control for both species. In P. monodon, regardless of whether the administered carotenoid was astaxanthin or $\beta$ carotene, carotenoid content in shrimp fed a diet supplemented with carotenoid was greater (two or fourfold) than that of shrimp fed an unsupplemented diet (Boonyaratpalin et al., 2001). A previous study in $P$. muelleri showed similar results: carotenoid levels were higher in the shrimp fed with supplemented diets with 50 and $100 \mathrm{mg}$ astaxanthin $\mathrm{kg}^{-1}$ after seven weeks of 
rearing under controlled conditions than initial animals (Díaz et al., 2011). The main carotenoids in penaeid exoskeletons are astaxanthin, astaxanthin esters, and $\beta$ carotene (Nègre-Sadargues et al., 1993; Meyers, 1994; Pan \& Chien, 2003). Carotenoids lead to deposition of mainly astaxanthin esters in the integument (carapace and epidermis), but the time required for each conversion (step) has never been established or documented (Chien \& Shiau, 2005; Sachindra et al., 2005).

Nevertheless, in the present study, concentrations of carotenoids in integument were lower than in ovaries for all treatments. In early ovarian development, free and esterified carotenoids are accumulated in the midgut gland; during secondary vitellogenesis, they seem to be mobilized from the midgut gland, transported in the hemolymph as caroteoglycolipoproteins, and sequestered to the ovaries where they accumulate in the oocytes as part of a significant egg yolk protein, lipovitellin (Vicent et al., 1988; Harrison, 1990). In tissues of mature wild $P$. vannamei females, a higher carotene concentration was observed compared with the reared ones, probably due to the higher concentrations and availability of carotenoids in the natural environment. Insufficient levels of carotenoids in captive shrimp might be related to unilateral eyestalk ablation of females because of its role in hormonal control in multiple processes, such as molting, metabolism, glucose balance, heart rate, gonadal maturation, and changes in color and pigment migration (Liñán-Cabello et al., 2003).

Oocytes require large amounts of energy to synthesize macromolecules during gonadal maturation, increasing the generation of singlet oxygen excessively. Antioxidant protective capacity was observed in shrimp under all treatments without significant differences among them; nevertheless, there were differences with initial individuals. The efficiency of carotenoids as antioxidants does not follow their capability as radical scavengers or the order of their oxidation potential (Han et al., 2006). The long-standing controversy of carotenoids' function as antioxidants may be related to extrapolation of properties determined in homogenous solutions to more complex biological systems, where other factors such as spatial organization and interaction between antioxidants become important (Liang et al., 2009).

The present study results show that astaxanthin and $\beta$-carotene added in broodstock diets promote gonadal maturation in both species. Carotenoids, such as astaxanthin and $\beta$-carotene, increase tolerance to oxidative stress, enhance the immune response, maybe an intracellular supply of oxygen, and protect cells by removing free radicals. The design of inexpensive, high-quality diets is fundamental as feed costs represent more than $50 \%$ of most aquaculture enterprises' production costs. The addition of carotenoid pigments as bioactive additives, which affect physiological and molecular processes under controlled conditions, is more evident from not being synthesized. It can be concluded that results indicate the usefulness of the addition of carotenoids addition in the diet of breeding females. Further studies may be performed to determine the important protective function of carotenoids to improve reproductive performance and transfer these dietary supplements to the early stages via the egg yolk.

\section{ACKNOWLEDGMENTS}

This research was funded by a grant PIP 112201701 00019CO from CONICET (Consejo Nacional de Investigaciones Científicas y Técnicas), Argentina.

\section{REFERENCES}

Association of Official Analytical Chemists (AOAC). 1997. Official methods of analysis of AOAC International. AOAC, Maryland.

Beckett, B.R. \& Petkovich, M. 1999. Evolutionary conservations in retinoid signaling and metabolism. American Zoology, 39: 783-795. doi: 10.1093/icb/ 39.4.783

Bonnie, F.T., Levin, A.A. \& Grippo, J.F. 1994. The discovery of 9-cis-retinoic acid a hormone that binds the retinoic-X-receptor. Trends in Endocrinology \& Metabolism, 5: 189-194. doi: 10.1016/1043-2760(94) 90076-0

Boonyaratpalin, M., Thongrod, S., Supamattaya, K., Britton, G. \& Schlipalius, L.E. 2001. Effects of $\beta$ carotene source, Dunaliella salina and astaxanthin pigmentation, growth, survival, and health of Penaeus monodon. Aquaculture Research, 32(1): 182-190. doi: 10.1046/j.1355-557x.2001.00039.x

Bray, W.A., Lawrence, A.L. \& Lester, L.J. 1990. Reproduction of eyestalk-ablated Penaeus stylirostris fed various levels of total dietary lipid. Journal of the World Aquaculture Society, 21: 41-52. doi: 10.1111/ j.1749-7345.1990.tb00952.x

Britton, G., Liaaen-Jensen, S. \& Pfander, H. 1995. Carotenoids. Springer, Berlin.

Chew, B.P. 1995. Antioxidant vitamins affect food animal immunity and health. Journal of Nutrition, 125: 18041808. doi: 10.1093/jn/125.suppl_6.1804S

Chew, B.P. \& Park, J.S. 2004. Carotenoid action on the immune response. Journal of Nutrition, 134: 257-261. doi: 10.1093/jn/134.1.257S

Chien, Y.H. \& Shiau, W.C. 2005. The effects of dietary supplementation of algae and synthetic astaxanthin on 
body astaxanthin, survival, growth, and low dissolved oxygen stress resistance of kuruma prawn, Marsupenaeus japonicus Bate. Journal of the Experimental Marine Biology and Ecology, 318: 201-211. doi: 10.1016/j.jembe.2004.12.016

Díaz, A.C. \& Fenucci, J.L. 2004. Effect of artificial nutrition on the induction of precocious maturation in Pleoticus muelleri Bate (Crustacea, Penaeoidea). Aquaculture Research, 35: 1166-1171. doi: 10.1111/j. 1365-2109.2004.01141.x

Díaz, A.C., Velurtas, S.M., Espino, M.L. \& Fenucci, J.L. 2014. Effect of dietary astaxanthin on free radical scavenging capacity and nitrite stress tolerance of postlarvae shrimp, Pleoticus muelleri. Journal of Agricultural and Food Chemistry, 62: 12326-12331. doi: $10.1021 /$ jf503754q

Díaz, A.C., Velurtas, S.M., Mendiara, S.N. \& Fenucci, J.L. 2013. Correlation between radical scavenging capacity and carotenoid profile during larval development of Pleoticus muelleri. Invertebrate Reproduction and Development, 51(1): 43-48. doi: 10.1080/079242 59.2012.659765

Díaz, A.C., Velurtas, S.M, Fernández-Giménez, A.V., Mendiara, S.N. \& Fenucci, J.L. 2011. Carotenoids from integument, muscle, and midgut gland of the red shrimp Pleoticus muelleri (Bate, 1888) (Crustacea, Penaeidea). Israeli Journal of Aquaculture - Bamidgeh, 63: 625-631.

Durica, D.S., Chung, A.C. \& Hopkins, P.M. 1999. Characterization of EcR and RXR gene homologs and receptor expression during the molt cycle in the crab, Uca pugilator. American Zoology, 39: 758-773.

Ghorbani-Vaghei, R., Abolhasani, M.H., Matinfar, A., Dadgar, S. \& Ghorbani, R. 2017. Production of artificial diets for female broodstock of western white shrimp (Litopenaeus vannamei) and study on their singular effect. Iranian Journal of Fisheries Sciences, 16(4): 1204-1213.

Han, R.M., Tian, X.Y., Wu, S.Y., Wang, P., Ai, X.C. \& Zhang, P.J. 2006. Radical cation generation from zeaxanthin and astaxanthin singlet and triplet excited states in chloroform. Photochemistry and Photobiology, 82: 538-546. doi: 10.1111/j.1751-1097.2004. tb00091.x

Halliwell, B. \& Gutteridge, J.M.C. 2001. Free radicals in biology and medicine. Oxford University Press, New York.

Harrison, K.E. 1990. The role of nutrition in maturation, reproduction, and embryonic development of decapod crustaceans: a review. Journal of Shellfish Research, 9(9): 1-28.

Harrison, K.E. 1997. Broodstock nutrition and maturation diets. In: D'Abramo, L.R., Conklin, D.E. \& Akiyama, D.M. (Eds.). Crustacean nutrition: advances in world aquaculture. World Aquaculture Society, Baton Rouge, pp. 390-408.

Huang, J.H., Jiang, S.G., Lin, H.Z., Zhou, F.L. \& Ye, L. 2008. Effects of dietary highly unsaturated fatty acids and astaxanthin on the fecundity and lipid content of pond-reared Penaeus monodon (Fabricius) broodstock. Aquaculture Research, 39: 240-251. doi: 10.1111/j.1365-2109. 2007. 01868.x

Katayama, T., Kamata, T., Shimaya, M., Deshimaru, O. \& Chichester, C.O. 1973. The biosynthesis of astaxanthin-VIII. The conversion of labeled $\beta$ carotene-15, 15'--3 $\mathrm{H} 2$ into astaxanthin in prawn, Penaeus japonicus Bate. Bulletin of the Japanese Society for the Science of Fish, 38: 1171-1175. doi: 10.1016/0305-0491(73)90317-9

Liang, J., Tian, Y., Yang, F., Zhang, J. \& Skibsted, L.H. 2009. Antioxidant synergism between carotenoids in membranes. Astaxanthin as a radical transfer bridge. Food Chemistry, 115: 1437-1442. doi: 10.1016/j.foodchem.2009.01.074

Liñán-Cabello, M.A. \& Paniagua-Michel, J. 2004. Induction factors from carotenoids and vitamin A during the ovarian maturation of Litopenaeus vannamei. Aquaculture International, 12: 583-592.

Liñán-Cabello, M.A., Paniagua-Michel, J. \& CentenoSavín T. 2003. Carotenoids and retinal levels in captive and wild shrimp, Litopenaeus vannamei. Aquaculture Nutrition, 9: 383-389. doi: 10.1046/j. 1365-2095.2003.00267.x

Liñán-Cabello, M.A., Paniagua-Michel, J. \& Hopkins, P. 2002. Bioactive role of carotenoids and retinoids in crustaceans. Aquaculture Nutrition, 8: 299-309. doi: 10.1046/j.1365-2095. 2002. 00221.x

Meyers, S.P. 1994. Developments in world aquaculture, feed formulations, and role of carotenoids. Pure and Applied Chemistry, 66(5): 1069-1076. doi: 10.1351/ pac199466051069

Nègre-Sadargues, G., Castillo, R., Petit, H., Sance, S., Gomez, M.R., Milicua, G.J.C., Choubert, G. \& Trilles, J.P. 1993. Utilization of synthetic carotenoids by the prawn Penaeus japonicus reared under laboratory conditions. Aquaculture, 110: 151-159. doi: 10.1016/ 0044-8486(93)90269-5

Niu, J., Tian, L., Liu, Y., Yang, H., Ye, C., Gao, W. \& Mai, K. 2009. Effect of dietary astaxanthin on growth, survival, and stress tolerance of postlarval shrimp, Litopenaeus vannamei. Journal of the World Aquaculture Society, 40: 795-802. doi: 10.1111/j.17497345.2009.00300.x

Niu, J., Li, C.H., Liu, Y.J., Tian, L.X., Chen, X., Huang, Z. \& Lin, H.Z. 2012. Dietary values of astaxanthin and canthaxanthin in Penaeus monodon in the presence and absence of cholesterol supplementation affect growth, nutrient digestibility, and tissue carotenoid 
composition. British Journal of Nutrition, 108: 80-91. doi: 10.1017/S0007114511005423

Paibulkichakul, C., Piyatiratitivorakul, S., Sorgeloos, P. \& Menasveta, P. 2008. Improved maturation of pondreared, black tiger shrimp (Penaeus monodon) using fish oil and astaxanthin feed supplements. Aquaculture, 282: 83-89. doi: 10.1016/j.aquaculture.2008. 06.006

Pan, C.H. \& Chien, Y.H. 2003. Concentration and composition of astaxanthin in black tiger prawn Penaeus monodon. Postlarvae fed Artemia sp. nauplii or mauxia shrimp Acetes intermedius. Journal of the World Aquaculture Society, 34: 57-65. doi: 10.1111/j. 1749-7345.2003.tb00039.x

Pangantihon-Kühlmann, M.P., Millamena, O. \& Chern, Y. 1998. Effect of dietary astaxanthin and vitamin A on the reproductive performance of Penaeus monodon broodstock. Aquatic Living Resources, 11(6): 403409. doi: 10.1016/S0990-7440(99)80006-0

Petriella, A.M. \& Díaz, A.C. 1987. Influence of eyestalk ablation upon molting frequency and gonadal maturation in the Argentine prawn Artemesia longinaris Bate. Journal of Aquaculture in the Tropics, 2: 17-24.

Pu, J., Bechtel, P.J. \& Sathivel, S. 2010. Extraction of shrimp astaxanthin with flaxseed oil: effects on lipid oxidation and astaxanthin degradation rates. Biosystems Engineering, 107: 364-371. doi: 10.1016/j. biosystemseng.2010.10.001

Regunathan, C. \& Wesley, S.G. 2006. Pigment deficiency correction in shrimp broodstock using Spirulina as a carotenoid source. Aquaculture Nutrition, 12: 425432. doi: 10.1111/j.1365-2095.2006.00444.x

Sachindra, N.M., Bhaskar, N. \& Mahendrakar, N.S. 2005. Carotenoids in different body components of Indian shrimp. Journal of the Science of Food and Agriculture, 85(1): 167-172. doi: 10.1002/jsfa.1977

Received: 10 September 2019; Accepted: 10 June 2020
Sawanboonchun, J., William, J.R., Robertson, D.A. \& Bell, J.G. 2008. The impact of dietary supplementation with astaxanthin on egg quality in Atlantic cod broodstock (Gadus morhua, L.). Aquaculture, 283: 97 101. doi: 10.1016/j.aquaculture.2008.06.024

Schiedt, K., Bischof, S. \& Glinz, E. 1993. [15] Metabolism of carotenoids and in vivo racemization of (3S, 3'S) astaxanthin in the crustacean Penaeus. Methods of Enzymology, 214: 148-168. doi: 10.1016/00766879(93)14062-N

Sokal, R. \& Rohlf, J. 1995. Biometry: the principles and practice of statistics in biological research. W.H. Freeman, New York.

Vicent, M., Ramos, L. \& Oliva, L. 1988. Variations qualitative et quantitative des pigments carotenoides dans l'ovaire et l'hepatopancreas de Penaeus schmitti au cours $\mathrm{du}$ maturations ovarienne. Archives Internationales de Physiologie et de Biochimie, 96: 155-164.

Wade, N., Goulter, K.C., Wilson, K.J., Hall, M.R. \& Degman, B.M. 2005. Esterified astaxanthin levels in lobster epithelia correlate with shell colour intensity: potential role in crustacean shell colour formation. Comparative Biochemistry and Physiology, 141: 307313. doi: $10.1016 /$ j.cbpc. 2005.04.004

Wouters, R., Zambrano, B., Espin, M., Calderon, J., Lavens, P. \& Sorgeloos, P. 2002. Experimental broodstock diets as partial fresh food substitutes in white shrimp Litopenaeus vannamei B. Aquaculture Nutrition, 8: 249-256. doi: 10.1046/j.1365-2095.2002. 00213.x

Young, A.J. \& Lowe, G.M. 2001. Antioxidant and prooxidant properties of carotenoids. Archives of Biochemistry and Biophysics, 385: 20-27. doi: 10.1006/abbi.2000.2149 